\title{
Susceptibility of Certain Pulse Grains to Callosobruchus maculatus (F.) (Bruchidae: Coleoptera), and Influence of Temperature on Its Biological Attributes
}

\author{
Osman M.A.M. ; M.F. Mahmoud and K.M. Mohamed \\ Plant Protection Department, Faculty of Agriculture, Suez Canal University 41522, Ismailia, Egypt
}

Received: 2 /3/2015

\begin{abstract}
Pulse grains in store suffer from great damage due to the attack of bruchid beetles, especially the pulse beetle (PB), Callosobruchus maculatus (Fabricius). The suitability of five common pulse species (chickpea, cowpea, field bean, pea and white bean) to infestation by C. maculatus was investigated. The effect of three legume species on the reproductive biology and adult longevity of $\mathrm{PB}$, as well as the influence of different temperature regimes on its development were also studied. Results indicated that the tested pulse species differed in their susceptibility to infestation with PB. Cowpea seeds were the most susceptible, followed by chickpea and peas; however, white bean and faba bean seeds showed high degree of tolerance even under heavy PB infestation. As for the effect of pulse species on certain biological aspects of $\mathrm{PB}$, the ovipositional period was the longest (17.13 days) for the adult females reared on cowpea, whereas the shortest (11.33 days) was recorded for those reared on chickpea. The mean number of eggs laid by PB female reared on cowpea (43.20 eggs) was higher than that laid by female reared on chickpea (35.00 eggs) and pea (32.20 eggs). The shortest longevity of adult males and females was recorded when reared on chickpea grains (14.67 and 20.67 days, respectively), while the corresponding longest periods were 15.60 and 25.53 days on cowpea grains. Pertaining to the influence of temperature, $\mathrm{PB}$ did not complete its development at $40^{\circ} \mathrm{C}$ and above. Temperature had a profound effect on the development of all immature stages of PB. The total developmental period of PB was negatively correlated to the increase of temperature; being longest (77.8 days) at the lowest tested temperature $\left(20^{\circ} \mathrm{C}\right)$ and shortest (20.7 days) at $35^{\circ} \mathrm{C}$. Longevity of either males or females also decreased as temperature increased.
\end{abstract}

Keywords: Callosobruchus maculatus, weight loss, reproductive biology, longevity, survival, temperature, pulse grains.

\section{INTRODUCTION}

Pulses are mainly referred to the grain legumes or reserved solely for the dry edible seeds harvested from various pulse crops, including all forms of peas and beans. They occupy a prominent place in agriculture and food systems worldwide, ranked as the second most important group of food crops complementary to the cereal crops in several aspects (Grahams and Vance, 2003). The seeds of pulse crops are valuable source of dietary protein; constituting $20-40 \%$ of their dry matter, according to species, genotype, and environment (Norton et al., 1985).

One of the major restrictions in production of pulses is the attack of insect pests, which inflict severe losses both in the field and storage (Sherma, 1989). Among these pests, bruchids (Coleoptera) incur greater importance. The bruchid or pulse beetle (PB), Callosobruchus maculatus (Fabricius) is regarded as the most important and cosmopolitan pest, seriously attacking several stored pulses. This insect is a potential storage pest for several species of pulse grains; i.e. cowpea, chickpea, garden pea and lentil etc. The damage caused by this insect pest is mostly due to its larval feeding on the nutritional contents inside the grains leading to weight loss, inferior quality and quantity proprieties (Atwal, 1976), and market value, as well as the germination potential of the infested grains (Booker, 1967). PB can cause a potential loss in legume ranged from $12-30 \%$ (FAO, 1994), 55-69\% loss in seed weight and $45.6-66.3 \%$ loss in protein contents of chickpea (Gugar and Yadav, 1978) and even up to
$100 \%$ loss in susceptible grain legumes (Borikar and Puri, 1985; Magagula and Maina, 2012).

The extent of weight loss due to the damage of PB is quite variable and depends on the storage period, storage conditions, storage containers and varieties of legume grains (Nchimbi-Msolla and Misangu, 2002; Mebeasilassie, 2004). Moreover, several biological attributes of PB such as adult life span, oviposition period, survival, fecundity, and the rate of population growth are greatly influenced by temperature. The different environmental conditions particularly temperature could be a detrimental factor on insect pest development and subsequently on its population growth parameters and degree of potential damage. In spite of the fact that insects are not subjected to constant temperatures in nature, controlled laboratory studies can provide valuable insights for understanding the development, reproduction and subsequent potential damage caused by insect pests (Summers et al., 1984). Thereby, this information may be useful to make a decision for future management of $C$. maculatus (Credland, 2006).

Temperature and the species of pulse grains have profound effects on the population, biological attributes of bruchids and in turn on the damage and weight loss in infested grains (Borikar and Puri, 1985; Lale and Vidal, 2003). Therefore, the present study aimed to investigate the susceptibility of different pulses to infestation by PB. Moreover, the influences of three pulse species, as well as six temperature regimes on some biological attributes of PB were also evaluated. 


\section{MATERIALS AND METHODS}

All experiments were conducted in the laboratory of Plant Protection Department, Faculty of Agriculture, Suez Canal University, Ismailia, Egypt. Susceptibility of different legume grains to infestation by $\mathrm{PB}$, and the effect of three legume species on the reproductive biology and longevity of emerged PB adults were examined under the prevailing environmental conditions of $25 \pm 2{ }^{\circ} \mathrm{C}$ and $60 \pm 10 \% \mathrm{RH}$. The development of PB on chickpea grains was also studied at six constant temperature regimes $\left(20,25,28,30,35\right.$ and $\left.40 \pm 1^{\circ} \mathrm{C}\right)$, and $60 \pm 10 \%$ R.H.

\section{Insect population and rearing technique}

The initial population of $C$. maculatus was taken from a laboratory culture maintained for several generations on dry seeds of chickpea in glass jars (3.5 L.).

\section{Pulse grain species}

Five pulse grain species (chickpea, cowpea, field bean, pea and white bean) were selected to screen their susceptibility to infestation by $C$. maculatus. Three kilograms of seeds of each species were purchased from a reliable source. Seeds were first oven-dried at $60^{\circ} \mathrm{C}$ for 72 hours to kill all immatures of bruchids and also to keep the moisture at the same level.

\section{Weight loss assessment of different pulse grains}

To assess the susceptibility of different pulse species, two experiments were conducted separately using the same experimental procedures.

\section{a. Infestation by PB adults}

Weight loss assessment was conducted on three replicates (50 g seeds) of each pulse grain species, placed separately in transparent plastic cans $(300 \mathrm{ml})$. Ten pairs of newly emerged PB of the same generation were introduced into plastic cans containing $50 \mathrm{~g}$ of seed pulse, closed by perforated plastic cover to allow good ventilation and maintained at the abovementioned prevailing conditions. Each treatment was regularly observed and weighed at least once a week (over 12 weeks), throughout three consecutive generations to estimate the weight loss of different grain pulse species.

\section{b. Infestation by PB Eggs}

In this experiment, seeds of each pulse species were separately exposed to appropriate population of $C$. macultus adult pairs $(50 q+50 \hat{\jmath})$ for 24 hours for eggs deposition on the surface of exposed seeds. After being exposed, all the adults were removed and the seeds examined by magnifying lens to make sure the egglaying. Seeds without PB eggs were excluded. Three replicates (50 grams seeds each) of each pulse grain species bearing $\mathrm{PB}$ eggs $(\approx 5$ eggs per one grain) were placed separately in transparent plastic cans $(300 \mathrm{ml})$ and closed by perforated plastic covers. Cans of each treatment were observed and weighed weekly to estimate the weight loss.
Effect of three legume species on the reproductive biology and longevity of PB

To study the effect of three legume species on the reproductive biology and longevity of $\mathrm{PB}$ adults, ten pairs of newly emerged PB adults ( $\leq 6$ hours old) were collected separately from PB culture reared on chickpea, cowpea and pea grains. Each couple was separately placed in a glass tube $(3 \times 10 \mathrm{~cm})$ and closed with piece of cotton. Five white bean grains were provided for each couple as ovipositional substrate. The white bean grains were daily examined by magnifying lens to count the number of deposited eggs, and the grains were replaced by other non-infested grains and so forth till the death of PB adults. Adults were also checked daily and the alive and dead adults were recorded until the death of all tested females or males. Ten replicates (each with a couple) for each tested grain species were performed.

\section{Effect of temperature on the development of PB}

The effect of temperature on the development of PB reared on chickpea grains was studied at six constant temperature regimes $\left(20,25,28,30,35\right.$ and $\left.40 \pm 1^{\circ} \mathrm{C}\right)$, $60 \pm 10 \%$ R.H. Twenty chickpea seeds bearing freshly $\mathrm{PB}$ eggs (one egg/grain) of homogenous age ( $\leq 6$ hours old) were placed in a clean glass tube $(3 \times 10 \mathrm{~cm})$ closed with piece of cotton. Three replicates were performed for each tested temperature. Grains were daily monitored for the development of $\mathrm{PB}$, and data were recorded in terms of egg hatching, occurrence of pupal champers, adult emergence, survival and longevity of emerged adults throughout the experiment for each tested temperatures.

\section{Statistical analyses}

Data were analyzed using one-way ANOVA using SAS System for Windows v. 9.1 (SAS Institute, 2004). In case of significant F-values, means were separated by LSD test at a 0.05 level of significance.

\section{RESULTS}

Susceptibility of different pulse grains to PB infestation based on weight loss

Table (1) shows the weight loss percentage of five pulse grain species at different time intervals of initial infestation by $C$. maculatus adult beetles. Seed weight loss differed significantly $(\mathrm{p}<0.05)$ among the tested legume species after 4 weeks $(\mathrm{F}=21.36 ; \mathrm{P} \leq 0.0001), 8$ weeks $(\mathrm{F}=20.63 ; \mathrm{P} \leq 0.0000), 10$ weeks $(\mathrm{F}=154.41 ; \mathrm{P}$ $\leq 0.0000)$, and 12 weeks $(\mathrm{F}=220.67 ; \mathrm{P} \leq 0.0000)$ of infestation (Table 1).

The same trend of significance $(p<0.05)$ was also recorded in the percentages of seed weight loss when seeds were infested by C. maculatus eggs (Table 2). Significant differences were found after 4 weeks $(\mathrm{F}=$ 195.06; $\mathrm{P} \leq 0.0000), 8$ weeks $(\mathrm{F}=170.44 ; \mathrm{P} \leq 0.0000)$, 10 weeks $(\mathrm{F}=153.19 ; \mathrm{P} \leq 0.0000)$, and 12 weeks $(\mathrm{F}=$ 288.982; $\mathrm{P} \leq 0.0000$ ) of infestation (Table 2).

It was observed that the weight loss increased gradually with the increase in time intervals due to 
increase of adult emergence across the overlapping generations of $C$. maculatus over the span of the experiment. Also, cowpea seeds were the most susceptible pulse species to $\mathrm{PB}$ infestation at a ratio of 35.93 and $44.58 \%$ seed weight loss 12 weeks post infestation by $\mathrm{PB}$ adults and eggs, respectively. The weight loss in chickpea seeds were 24.93 and $37.05 \%$, followed by pea seeds that amounted to 9.63 and $17.90 \%$ in both experiments, respectively. White bean and faba bean seeds showed high degree of tolerance to C. maculatus. Seed weight loss after 12 weeks of infestation by adult beetles and eggs were 2.03 and $1.12 \%$ for white beans; 1.92 and $1.56 \%$ for faba beans (Tables 1 and 2).

Table (1): Mean of weight loss $( \pm \mathrm{SE})$ in certain legume grains at different time intervals after infestation by adults of $C$. maculatus

\begin{tabular}{lcccc}
\hline \multirow{2}{*}{ Legume grains } & \multicolumn{4}{c}{ Weight loss \% after, } \\
\cline { 2 - 5 } & $\mathbf{4}$ weeks & $\mathbf{8}$ weeks & $\mathbf{1 0}$ weeks & $\mathbf{1 2}$ weeks \\
\hline Chickpea & $3.39 \pm 0.05 \mathrm{a}$ & $5.77 \pm 0.23 \mathrm{ab}$ & $10.13 \pm 0.85 \mathrm{~b}$ & $24.93 \pm 0.78 \mathrm{~b}$ \\
Pea & $1.27 \pm 0.13 \mathrm{~b}$ & $3.13 \pm 0.12 \mathrm{bc}$ & $4.07 \pm 0.21 \mathrm{c}$ & $9.63 \pm 0.77 \mathrm{c}$ \\
Cowpea & $3.57 \pm 0.55 \mathrm{a}$ & $9.16 \pm 1.54 \mathrm{a}$ & $21.47 \pm 1.09 \mathrm{a}$ & $35.93 \pm 1.82 \mathrm{a}$ \\
White bean & $0.82 \pm 0.21 \mathrm{~b}$ & $1.16 \pm 0.26 \mathrm{c}$ & $1.23 \pm 0.28 \mathrm{c}$ & $2.03 \pm 0.26 \mathrm{~d}$ \\
Faba bean & $0.53 \pm 0.37 \mathrm{~b}$ & $1.07 \pm 0.60 \mathrm{c}$ & $1.12 \pm 0.60 \mathrm{c}$ & $1.92 \pm 0.7 \mathrm{~d}$ \\
F & 21.36 & 20.63 & 154.41 & 220.67 \\
P & 0.0001 & 0.00 & 0.00 & 0.00 \\
Sig. & $* * *$ & $* * *$ & $* * *$ & $* * *$ \\
LSD 0.05 & 0.99 & 2.38 & 2.17 & 3.18 \\
\hline
\end{tabular}

Means in the same column followed by the same letters are not significantly different (LSD, $\mathrm{P} \leq 0.05)$

Table (2): Mean of weight loss $( \pm \mathrm{SE})$ in certain legume grains at different time intervals after infestation by eggs of $C$. maculatus

\begin{tabular}{lcccc}
\hline \multirow{2}{*}{ Legume grains } & \multicolumn{4}{c}{ Weight loss \% after, } \\
\cline { 2 - 5 } & $\mathbf{4}$ weeks & $\mathbf{8}$ weeks & $\mathbf{1 0}$ weeks & $\mathbf{1 2}$ weeks \\
\hline Chickpea & $13.54 \pm 1.40 \mathrm{~b}$ & $20.61 \pm 2.29 \mathrm{~b}$ & $24.08 \pm 2.39 \mathrm{~b}$ & $37.05 \pm 2.01 \mathrm{~b}$ \\
Pea & $4.62 \pm 0.22 \mathrm{c}$ & $10.25 \pm 0.39 \mathrm{c}$ & $12.21 \pm 1.01 \mathrm{c}$ & $17.90 \pm 1.49 \mathrm{c}$ \\
Cowpea & $23.74 \pm 0.71 \mathrm{a}$ & $35.63 \pm 0.87 \mathrm{a}$ & $37.49 \pm 1.06 \mathrm{a}$ & $44.58 \pm 0.55 \mathrm{a}$ \\
White bean & $0.20 \pm 0.12 \mathrm{~d}$ & $0.51 \pm 0.08 \mathrm{~d}$ & $0.53 \pm 0.08 \mathrm{~d}$ & $1.12 \pm 0.10 \mathrm{~d}$ \\
Faba bean & $0.62 \pm 0.23 \mathrm{~d}$ & $1.32 \pm 0.50 \mathrm{~d}$ & $1.35 \pm 0.50 \mathrm{~d}$ & $1.56 \pm 0.58 \mathrm{~d}$ \\
F & 195.06 & 170.44 & 153.19 & 288.982 \\
P & 0.00 & 0.00 & 0.00 & 0.00 \\
Sig. & $* * *$ & $* * *$ & $* * *$ & $* * *$ \\
LSD 0.05 & 2.27 & 3.56 & 4.01 & 3.70 \\
\hline
\end{tabular}

Means in the same column followed by the same letters are not significantly different (LSD, $\mathrm{P} \leq 0.05)$.

Effect of three legume species on the reproductive biology of PB

\section{Effects of pulse species on ovipositional periods}

The effects of three different pulse species on the ovipositional periods of PB females are depicted in Figure (1). Data indicated that the tested pulse species had no significant differences on the pre- and postovipositional periods of $\mathrm{PB}$. The pre-ovipositional periods lasted 3.00, 1.67 and 2.00 days for adult females reared on Pea, chickpea and cowpea, respectively. The respective post-ovipositional periods were $7.67,7.67$ and 6.00 days. 
As for ovipositional period, the longest period was 17.13 days for PB females reared on cowpea, whereas the shortest was 11.33 days for those reared on chickpea (Figure 1). Obviously, there were significant differences among the tested pulse species on the ovipositional periods $(\mathrm{F}=5.98 ; P=0.0052)$.

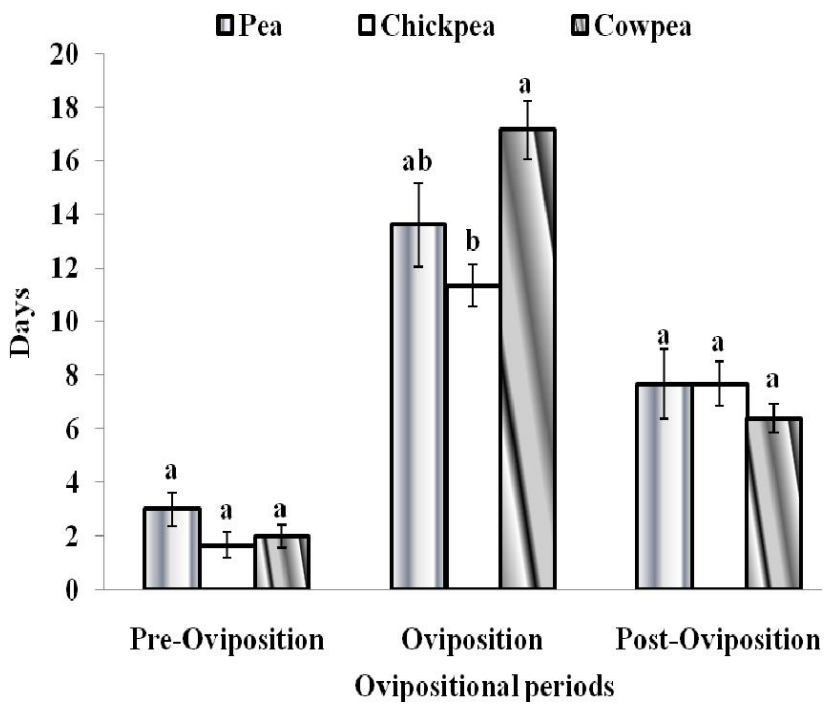

Figure (1): Effects of cowpea, chickpea and pea grains on the ovipositional periods of PB.

Bars with different letters indicate significant difference $(\mathrm{P}<0.05)$

\section{Effects of pulse species on fecundity}

Data in Figure (2) showed that there were significant differences between PB females reared from different pulse species in terms of total lifetime fecundity $(\mathrm{F}=3.236 ; P=0.0493)$. The total numbers of deposited eggs by PB females reared on cowpea were significantly higher than those laid by females reared on chickpea and pea. The respective total fecundity was 43.20, 35 and 32.20 eggs/female. As for daily fecundity, there were no significant differences among the tested females reared on the three studied pulse species (Figure 2).

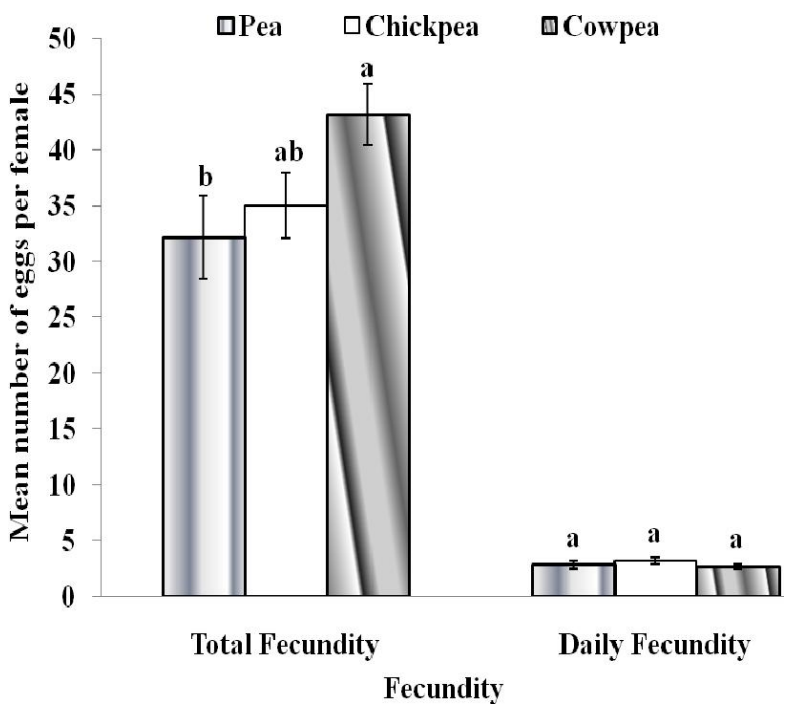

Figure (2): Mean $( \pm \mathrm{SE})$ of daily and total fecundity of PB reared on different pulse species.

Bars with different letters indicate significant difference $(\mathrm{P}<0.05)$.

\section{Effects of pulse species on adult longevity}

As shown in Figure (3), longevity of either males or females was the longest when reared on cowpea grains at 15.60 and 25.53 days, respectively. The shortest longevity of adult males and females was recorded of beetles reared on chickpea grains at 14.67 and 20.67 days, respectively. Statistical analyses revealed that significant differences existed among longevities of adult females reared on different tested pulse grains $(\mathrm{F}=5.547 ; \mathrm{P}=0.0073)$. However, no significant differences were observed among longevities of the adult males $(\mathrm{F}=0.172 ; P=0.842)$.

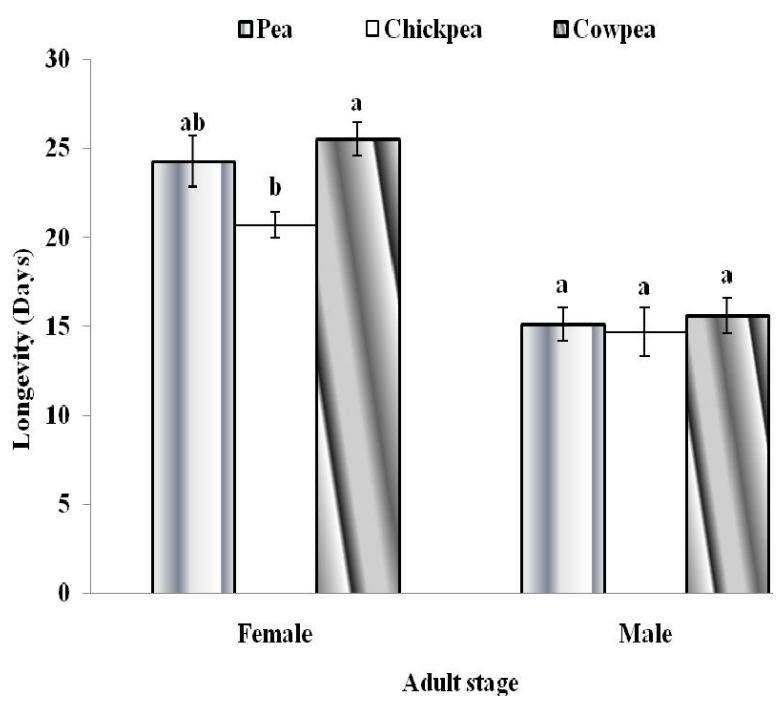

Figure (3): Mean $( \pm \mathrm{SE})$ of male and female longevity of PB reared on different pulse species.

Bars with different letters indicate significant difference $(\mathrm{P}<0.05)$

\section{Effect of temperature on the development of PB}

Observations on the effect of different temperatures on the development of $\mathrm{PB}$ showed that the $\mathrm{PB}$ eggs incubated at $40^{\circ} \mathrm{C}$ failed to hatch or didn't complete their development, with no adult emergence occurred. Therefore, the obtained results on the influence of temperatures on PB development were tabulated only for five temperature regimes (Table 3 ).

As shown in Table (3), temperature had a significant effect on the development of all immature stages of PB. The incubation period was significantly affected by temperature and there was significant decreases among tested temperatures $(\mathrm{F}=73.926$; $P=$ $0.0000)$. While the shortest incubation period was 3.7 days at $35^{\circ} \mathrm{C}$, the longest one (13.8 days) was observed at $20^{\circ} \mathrm{C}$. The incubation period was intermediate in the other tested temperatures; being 4.2, 4.8 and 6.5 days at 25,28 and $30^{\circ} \mathrm{C}$, respectively.

As for total larval development, there also was a significant effect of temperature on this stage $(\mathrm{F}=$ $70.505 ; P=0.0000)$. The total larval period was shortest (12.3 days) at $35^{\circ} \mathrm{C}$, followed by 13.7 days at $30^{\circ} \mathrm{C}$. The longest larval duration was obtained at the lowest temperature of $20^{\circ} \mathrm{C}$; being 42.7 days. The larval duration at 25 and $28^{\circ} \mathrm{C}$ was in-between; being 21.5 and 15.8 days, respectively (Table 3 ). 
Data in Table (3) also indicated that temperature should a negative correlation with pupal duration $(\mathrm{F}=$ 115.625; $P=0.0000)$. The pupal periods lasted 4.7, 5.9, $7.1,10.3$ and 21.3 days at $20,25,28,30$ and $35^{\circ} \mathrm{C}$, respectively. The total developmental period of $\mathrm{PB}$ immatures was negatively correlated to the increase of temperatures; being longest ( 77.8 days) at $20^{\circ} \mathrm{C}$ and shortest (20.7 days) at $35^{\circ} \mathrm{C}$ (Table 3). Statistical analysis showed that there were significant differences among the tested temperatures in terms of total developmental periods of $\mathrm{PB}(\mathrm{F}=151.236 ; P=0.0000)$.

As for the generation survival (Egg-adult), significant differences were found among tested temperatures in term of overall generation survival $(\mathrm{F}=$ 4.94; $P=0.002)$. The greatest generation survival $(91.27 \%)$ was recorded at $28^{\circ} \mathrm{C}$, whereas the lowest generation survival (72.1 and $78.2 \%$ ) was observed at 35 and $20^{\circ} \mathrm{C}$, respectively (Table 3 ).

\section{Effects of temperature on adult longevity}

Generally, females of PB lived longer than males irrespective of rearing temperatures and holding conditions. Adult longevity decreased as temperature increased. Longevity of PB females lasted 25.7, 21.31, $16.9,13.7$ and 11.3 days at $20,25,28,30$ and $35^{\circ} \mathrm{C}$, respectively (Figure 4). Apparently, there were significant differences among tested temperatures in terms of female longevity $(\mathrm{F}=35.09 ; \quad P=0.0000)$.
Pertaining to males, their longevities at the respective temperatures were 16.3, 14.6, 13.0, 11.2 and 9.7 days (Figure 4). Significant differences were observed in male longevity among the studied temperatures $(\mathrm{F}=14.347 ; P=0.0000)$.

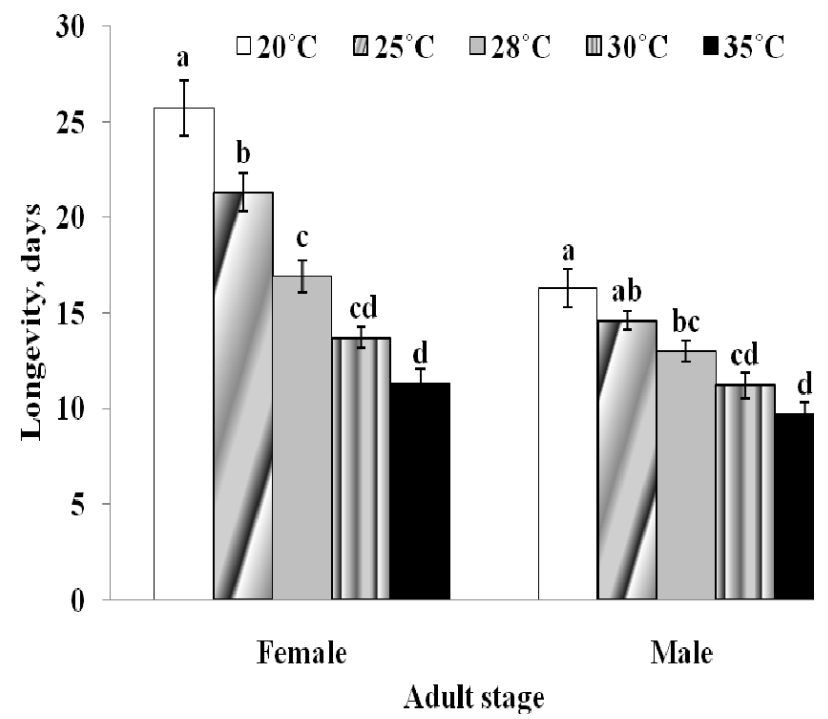

Figure (4): Mean $( \pm \mathrm{SE})$ of male and female longevity of $\mathrm{PB}$ at different tested temperature regimes. Bars with different letters in the same treatment indicate significant difference $(\mathrm{P}<0.05)$.

Table (3): Effects of five temperature regimes $\left(20,25,28,30\right.$ and $\left.35^{\circ} \mathrm{C}\right)$ and $60 \pm 10 \%$ R.H. on the immature development of PB on chickpea grains

\begin{tabular}{lccccc}
\hline Temperature & $\begin{array}{c}\text { Incubation } \\
\text { period (days) }\end{array}$ & $\begin{array}{c}\text { Larval period } \\
\text { (days) }\end{array}$ & $\begin{array}{c}\text { Pupal period } \\
\text { (days) }\end{array}$ & $\begin{array}{c}\text { Total } \\
\text { developmental } \\
\text { period (days) }\end{array}$ & $\begin{array}{c}\text { Generation } \\
\text { Survival } \\
\text { (\%) }\end{array}$ \\
\hline $\mathbf{2 0}{ }^{\circ} \mathbf{C}$ & $13.8 \pm 0.8 \mathrm{a}$ & $42.7 \pm 2.8 \mathrm{a}$ & $21.3 \pm 0.9 \mathrm{a}$ & $77.8 \pm 3.5 \mathrm{a}$ & $78.2 \pm 3.02 \mathrm{ab}$ \\
$\mathbf{2 5}^{\circ} \mathbf{C}$ & $6.5 \pm 0.5 \mathrm{~b}$ & $21.5 \pm 0.9 \mathrm{~b}$ & $10.3 \pm 0.7 \mathrm{~b}$ & $38.3 \pm 1.5 \mathrm{~b}$ & $85.6 \pm 3.38 \mathrm{a}$ \\
$\mathbf{2 8}^{\circ} \mathbf{C}$ & $4.8 \pm 0.4 \mathrm{bc}$ & $15.8 \pm 1.1 \mathrm{bc}$ & $7.1 \pm 0.5 \mathrm{c}$ & $27.7 \pm 1.4 \mathrm{c}$ & $91.2 \pm 2.9 \mathrm{a}$ \\
$\mathbf{3 0}^{\circ} \mathbf{C}$ & $4.2 \pm 0.3 \mathrm{c}$ & $13.7 \pm 0.6 \mathrm{c}$ & $5.9 \pm 0.4 \mathrm{c}$ & $23.8 \pm 0.7 \mathrm{c}$ & $88.4 \pm 3.79 \mathrm{a}$ \\
$\mathbf{3 5}{ }^{\circ} \mathbf{C}$ & $3.7 \pm 0.3 \mathrm{c}$ & $12.3 \pm 0.7 \mathrm{c}$ & $4.7 \pm 0.4 \mathrm{c}$ & $20.7 \pm 0.9 \mathrm{c}$ & $72.1 \pm 4.3 \mathrm{~b}$ \\
\hline $\mathbf{F}$ & 73.93 & 70.50 & 115.63 & 151.24 & 4.94 \\
$\mathbf{P}$ & 0 & 0 & 0 & 0 & 0.0022 \\
Sig. & $* * *$ & $* * *$ & $* * *$ & $* *$ & $* 4$ \\
$\mathbf{L S D} \mathbf{0 . 0 5}$ & 1.3785 & 4.24695 & 1.7818 & 5.4202 & 10.029 \\
\hline
\end{tabular}

Means within a column followed by different letters are significantly different: $\mathrm{P}<0.05$.

\section{DISCUSSION}

Pulse beetle, $C$. maculatus, is a serious oligophagous field-to-store insect pest infesting dried cowpeas and other 14 related pulse species in the store. (Huignard et al., 1996). However, different pulse species show various degree of susceptibility to infestation of $C$. maculatus. The present results indicated that the cowpea seeds were the most susceptible pulse species as the greatest weight loss was recorded, followed by chickpea and peas; however, white bean and faba bean seeds showed high degree of tolerance to $C$. maculatus even under heavy infestation conditions. These findings are in agreement with those of Shivanna et al. (2011) who found that the cowpea was the most preferred host, while field bean was 
comparatively less preferred one, accompanied with prolonged developmental period. It was also observed that $C$. maculatus prefers legumes with smooth seed coats as cowpea and white bean for oviposition. However, in white beans, most newly hatching larvae died during the first instar since they were unable to penetrate the seed coat. These observations are in accordance with those reported earlier (Girish et al., 1974; Mwanze et al., 1975; Southgate, 1979). Likewise, Singh et al. (1977) concluded that the ovipositional preference on white bean is not an indication of suitability of a host for larval development. Also, Bhaduria and Jakhmola (2006) reported that the ovipositional preference and survival of $C$. maculatus on black gram, French bean and pigeon pea were less preferred for oviposition, while cowpea was the most preferred host for oviposition and survival.

Results obtained in this study revealed the obvious effects of various legumes species on reproduction, fecundity and adult longevity of $C$. maculatus. Adult females emerged from cowpea grains have the longest ovipositional period (17.13 days), highest number of laid eggs (43.20 eggs/female) and the shortest longevity compared to those emerged from chickpea and pea grains. These findings are in harmony with those recorded earlier by Wijeratne (1998) and Kazemi et al. (2009) who concluded that host species influenced egg and adult production, and cowpea was the adapted host for $C$. maculatus to produce higher population as it compared to other seeds. Previous studies on the reproduction and fecundity of $C$. maculatus confirmed the importance of the nutritional value of the seeds on the fecundity of PB (El-Halfawy et al., 1972; Cope and Fox, 2003).

Temperature had a profound effect on development of C. maculatus, which failed to develop at $40^{\circ} \mathrm{C}$ and above. As the temperature increased, there was a significant decrease in the total developmental period, as well as in the adult longevity. These findings were in consistence with those reported earlier by Adhikary and Anandamay (2012) who found that the developmental time from egg hatching to adult emergence and longevity of males and females of $C$. maculatus were shortest at $30^{\circ} \mathrm{C}$ and longest at $25^{\circ} \mathrm{C}$. In this study, temperature ranged between 25 and $30^{\circ} \mathrm{C}$ was more favorable to reproduction of $C$. maculatus as indicated by shorter developmental time and high survival rate, which in turn affected the degree of induced damage. These results are in line with those of Lale and Vidal (2003) who found that temperature influenced oviposition and progeny development of $C$. maculatus and $C$. subinnotatus (Pic.) significantly more than humidity. They also found that the egg-laying and progeny development in C. maculatus were optimal at $35^{\circ} \mathrm{C}$. In contrast, oviposition and progeny development in C. subinnotatus were optimal at $30^{\circ} \mathrm{C}$. Similarly, Davey (1965) reported that the minimum and maximum temperatures required for the development of $C$. chinensis L. ranged between 20 to $35^{\circ} \mathrm{C}$ and the relative humidity ranges between $10-90 \%$. Lale and Vidal (2003) reported that no progeny development from adult bruchid beetles exposed to $40^{\circ} \mathrm{C}$. In this respect,
Loganathan et al. (2011) used lower and high temperatures to manage $C$. maculatus and thermal disinfestation was a promising of physical insect control mean for stored grains.

In conclusion, the obtained results clearly demonstrated that pulse species differed significantly in their susceptibility to $\mathrm{PB}$ and cowpea seeds were the most susceptible, followed by chickpea and peas. On the other hand, the reproductive biology and longevity of $\mathrm{PB}$ adults are influenced by the pulse species they are reared on. Cowpea grains were more favorable for oviposition and extended longevity of PB adults compared to chickpea and pea grains. Likewise, temperature has a profound influence on the development of all immature stages of PB. As the temperature increased, there was a significant decrease in developmental duration and adult longevity. High constant temperature at $40^{\circ} \mathrm{C}$ is adversely affecting $\mathrm{PB}$ development through its lethal impact on PB eggs. Indeed, it could be suggested that the high temperature of $40^{\circ} \mathrm{C}$ and above can be used in store to protect pulse grains from the PB infestation. However, further studies are needed to determine the lethal low and high temperatures that can be used as thermal disinfestations without affecting to the quality of stored grains.

\section{REFERENCES}

Adhikary, P. and B. Anandamay 2012. Effect of temperature on biology of Callosobruchus maculatus (F.). Indian J. Entomol., 74(3):261-266.

Atwal, A.S. 1976. Insect pests of stored grain and other stored products. In: Agricultural pests of India and South East Asia. New Delhi, India; Kalyani Publishers, pp: 389-415.

Bhaduria, N.S. and S.S. Jakhmola 2006. Effect of intensity of infestation caused by pulse beetle on extent of losses and seed germination in different pulses. Indian J. Entomol., 68: 92-94.

Booker, R.H. 1967. Observation on three bruchids associated with cowpea in northern Nigeria. J. Stored Prod. Res. 3: 1-15.

Borikar, P.S. and S.N. Puri 1985. Damages and losses caused by Callosobruchus chinensis to different legumes stored in selected containers. Agric. Sci. Digest.5: 108-110.

Cope, J.M. and C.W. Fox 2003. Oviposition decisions in the seed beetle, Callosobruchus maculatus (Coleoptera: Bruchidae): effects of seed size on superparasitism. J. Stored Prod. Res., 39: 355-365.

Credland, P.F. 2006. Laboratory studies of insect behaviour and pest control; a neglected interface or different worlds? Examples from studies with Callosobruchus maculatus (F.) (Coleoptera: Bruchidae). Proceedings of the $9^{\text {th }}$ International Working Conference on Stored Product Protection, Campinas, São Paulo, Brazil, 423-432. 
Davey, P. M. 1965. Insect pests of stored products in the tropics and the commodities and conditions in which they occur. Trop. Stored Prod. Inf. 10: $377-$ 386.

El-Halfawy, M.A., J.M. Nakhla and N.H. Isa 1972. Effect of food on the fecundity, longevity and development of the southern cowpea weevil Callosobruchus maculatus F. Agricultural Research Review, 5(91): 67-70.

FAO, 1994. Grain storage techniques, evaluation and trends in developing countries. FAO Agricultural Services Bulletin, 109, Rome, Italy.

Girish, G. K., K. Singh and K. Murthy 1974. Studies on oviposition and development of Callosobruchus maculatus (Fab.) on various stored pulses. Bull. Grain Tech., 12:113-116.

Grahams, P.H. and C.P. Vance 2003. Legumes: Importance and constraints to greater use. Plant Physiol. 131:872-877.

Gugar, G.T. and T.D. Yadav 1978. Feeding of Callosobruchus maculatus and Callosobruchus chinensis Linn. in green gram. Indian. J. Entomol., 40: 108-12.

Huignard, J., J.C. Baehr, P. Desroches and N. Mandon 1996. Adaptation of a Callosobruchus maculatus strain to Vicia faba, as its new host plant. Proceedings of the $9^{\text {th }}$ International Symposium on Insect-Plant Relationships Series Entomologica, 53: 156-159.

Kazemi F., A.A. Talebi, Y. Fathipour and S. Farahani 2009. A Comparative Study on the Effect of Four Leguminous Species on Biological and Population Growth Parameters of Callosobruchus maculatus (F.) (Col.: Bruchidae). Adv. Environ. Biol., 3(3): 226-232

Lale, N.E.S and S. Vidal 2003. Effect of constant temperature and humidity on oviposition and development of Callosobruchus maculatus (F.) and Callosobruchus subinnotatus (Pic) on bambara groundnut, Vigna subterranea (L.) Verdcourt. J. Stored Prod. Res., 39: 459-470.

Loganathan, M., D.S. Jayas, P.G. Fields and N.D.G. White 2011. Low and high temperatures for the control of cowpea beetle, Callosobruchus maculatus (F.) (Coleoptera: Bruchidae) in chickpeas. J. Stored Prod. Res., 47: 244-248.

Magagula, C.N. and Y.T. Maina 2012. Activity of Callosobruchus maculatus (F.) (Coleoptera: Bruchidae) on selected bambara groundnut (Vigna subterranea L. Verdc.) landraces and breeding lines. Journal of Biology, Agriculture and Healthcare, 2(3): 82-94.
Mebeasilassie A. 2004. Studies on the pest status of bean bruchid and managements of major bruchid species in central rift valleys of Ethiopia. M.Sc. Thesis, School of Graduate Studies. Addis Ababa University, Ethiopia. Pp 95.

Mwanze, K.F., E. Hober and C.W. Pitts 1975. Evidence for ovipositional preference of Callosobruchus maculatus for cowpea varieties. Environ. Entomol., 4:409-412.

Nchimbi-Mosolla, S. and R.N. Misangu 2002. Seasonal distribution of common bean bruchid species in selected areas in Tanzania, Proceedings of the Bean Seed Workshop, Arusha, Tanzania, 12-14 January, 2001. Bean/Cowpea Collaborative Research Support Program-East Africa, Pp 5.

Norton G., Bliss F.A. and R. Bressani 1985. Biochemical and nutritional attributes of grain legumes. In Summerfield R. J., Roberts E. H. Grain legume crops. London: Collins, p. 73-114.

SAS Institute, 2004. SAS/STAT V. 9.1 SAS institute Inc., Cary, NC. USA.

Sherma, S.S. 1989. Review of literature of the losses caused by Callosobruchus species (Bruchidea: Coleopetra) during storage of pulses. Bull. Grain Technol., 22: 62-68.

Shivanna, B.K., B.N. Ramamurthy, N.B. Gangadhara, D.S. Gayathri, H. Mallikarjunaiah and N.R. Krishna 2011. Varietal screening of cowpea against pulse beetles, Callosobruchus maculatus (Fab.) and C. analis (Fab.). Int. J. Science and Nature, 2(2): 245-247.

Singh, S., S.C. Odak and Z. Singh 1977. Studies on preference of pulse beetle (Callosobruchus chinensis Linn.) for different hosts. Bull. Grain Tech., 15:20-26.

Southgate, B.J. 1979. Biology of the Bruchidae. Ann. Rev. Entomol., 24:449-473.

Summers C.G., R.L. Coviello and A.P. Gutierrez 1984. Gutierrez Influence of constant temperatures on the development and reproduction of Acyrthosiphon kondoi (Homoptera: Aphididae). Environ. Entomol., 13:236-242.

Wijeratne, P.M., 1998. Variation in egg and adult production of Callosobruchus maculatus (F.) and Callosobruchus chinensis (L.) and the effect of egg density and oviposition site limitation. Tropical Agricultural Research and Extension, 1(2): 136-142. 